Society for the Anthropology of Work • Essential Labor

\title{
Essential Space for \\ Essential Workers: \\ Responding to COVID-19
}

\section{Alexandra Baybutt}

Published on: Dec 15, 2020

DOI: $10.21428 / 1 d 6$ be30e.55476c6c

License: Creative Commons Attribution 4.0 International License (CC-BY 4.0). 
In early 2020, volunteers in London established a semiformal food and essentials hub to support the efforts of local hospital workers dealing with victims of an as yet unknown virus. For its organizers, all National Health Service (NHS) workersirrespective of position, role, and pay scale-were responding to the same challenge. Each was equally important for sustaining public health, and for enabling the work of one another. In spite of its partial privatization and moves to outsource labor, the NHS was to be understood as a whole system in which the essential work of each part was necessary for the functioning of the whole.

In the months that followed, a number of civil society initiatives cropped up with the intention of aiding the critical work of the NHS. The food and essentials hub was one example. It was auxiliary in relation to the NHS's essential work, but it was no less essential itself. The hub's volunteers took in donations from individuals and businesses and then distributed them to NHS workers, who would otherwise have put themselves and others at risk simply by going to the grocery store.

During the COVID-19 pandemic, essential workers performed labor that has been chronicled in this Exertions forum and will surely be in others for years to come. In this short essay, I want to point to the conditions of that labor's existence and, in particular, the volunteer labor of maintaining it. This is a form of labor marked by all sorts of political and ethical entanglements, involving questions about what efforts are more or less critical to the functioning of the core system. This essay foregrounds the volunteers who maintain the essential labor of the NHS. Their labor is bound up with what Emily Beausoleil (2015: 4) would call a "dispositional ethics of encounter." Such an ethics consists in responsibility, where being responsible means remaining receptive and responsive within the context of the encounter (see Despret 2004, 2016; Barad 2007; Haraway 2016).

What kinds of labor-organizational, redistributive, affective, and so on-are needed for reproducing essential labor? How do (volunteer) essential laborers perceive their responsibilities, and especially their responsibilities to others? In what follows, I trace these questions across a series of encounters in the hub, as a space grounded by a shared condition of vulnerability. 
I self-isolated for a week before it was common practice in the United Kingdom, and I was craving human company. So I found my way into the hallway of a neighbor I had recently met in a mutual aid Whatsapp group. Her speech was fast, hopping from topic to topic. But I gleaned a few things: she is a childminder who had lost her job in the current moment. She is a mother of young adults. She was about to drive somewhere to collect something. She has a talent for remembering people's skills and needs so that she can join them up as opportunities arise.

A day or so later, I learned that my neighbor and another WhatsApp acquaintance had repurposed a community center as a donation-based hub for local hospital workers. I contributed a few things from my cupboards, but I also decided to volunteer at the hub, drawn by its potential to redistribute resources and disrupt hierarchies and divides within the NHS. For instance, meals donated to accident and emergency workers by local restaurants were going to waste overnight until one of the workers brought the leftovers to the hub to be shared back out. While NHS workers were not themselves volunteers at the hub, many did follow its activities. Some would take supplies to share with other colleagues on the wards: a morning snack, sugar for the tea room, plastic cups.

I look at the names as the workers come in, two at a time. I write them down and ask for their department, archiving how many people we are helping and what roles they perform. We volunteers also become accustomed to staging photos so that the initiative does not receive criticism on social media for not adhering to the guidelines for social distancing. The problem is that in the hospital none of the workers practice this new spatial choreography, and so in the hub volunteers have to become the arbiters of space: for the health of those gathered, but also for the reputation of the initiative. This care for endurance is a challenge for the volunteers, who must insist on upholding official government guidelines as well as unofficial scrutiny in unobtrusive ways. The presentation of the work of the hub through social media does not disclose the sometimes less-than-cheerful experiences of coordinating, often via a surreptitious WhatsApp message, with new volunteer colleagues. Clara Han (2016: 83) has pointed out that concealing allows for enduring to endure. The endurance of the hub requires showing a good flow of donations and happy recipients, demonstrating trust and functionality. But this means that some of the organizational labor of volunteers, which takes place through digital communication or in a quiet sidebar, must be retold or concealed. 


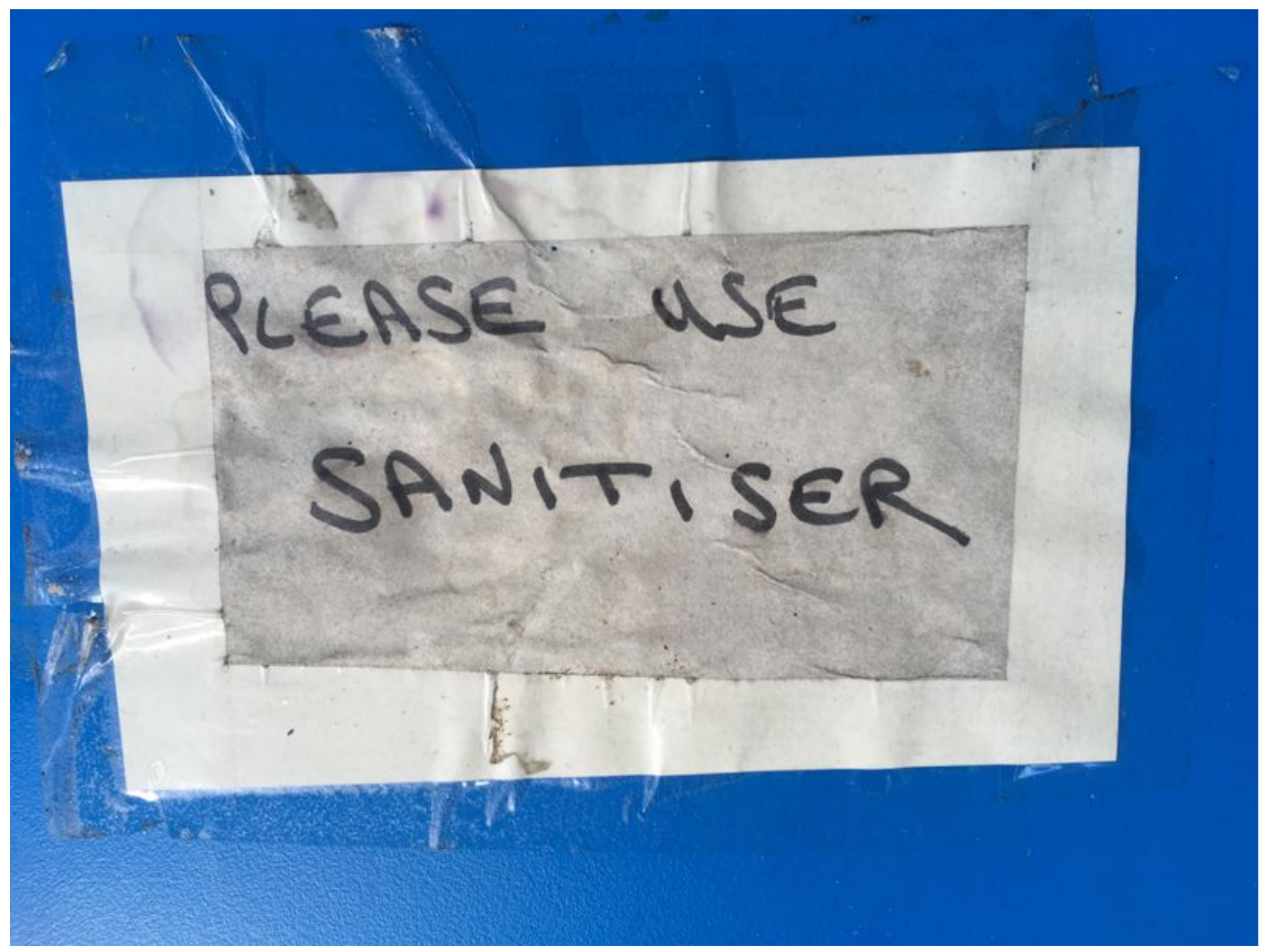

Photo by Alexandra Baybutt.

As a volunteer, my contributions are prosaic: I decant big bags of sugar, flour, or pasta into small tubs. I clean the toilet, compress the cardboard boxes, take the bins out, wipe surfaces and handles. I find donations stashed in a hurry under tables, and ask if we are expecting a delivery any time soon. As March wears on, the initiative gains access to storage space at a mosque, one block down the road. I wheel a shopping trolley back and forth, trying not to scrape the parked cars. The rest of my time is filled with making eye contact with people, often behind their masks and mine. I speak cheerfully, asking how they are, whether they are going or coming back from a shift. The amount and quality of this chat depends on how much someone wants or needs to connect in that moment. The point is that we open that potential space.

\section{Even if I didn't need anything, I'd come in here. It feels like a family. ${ }^{1}$}

At a time when people cannot often connect in person, these transactions take on a new intensity. I listen to unguarded, unedited thoughts in torrents. People let off steam. I hear that a baby has been born at the hospital from a mother with the virus, 
and it's hard to know whether it was passed on in utero or caught after delivery. Sometimes, these bits of news are prefaced by I shouldn't tell you this. I listen to the exhaustion, the camaraderie between colleagues, and the delirium found in the crossfade between work hours ending and yearned-for repose. A young nurse tells me she came from the Philippines to work just a month before the outbreak, and that she doesn't know many people. A consultant tells me of the new relationship she has with her sister, who now gives her ideas for recipes based on the contents of her cupboard.

The volunteers become a listening center, hovering by tables of food and cosmetics around which NHS workers revolve counterclockwise. One morning, I am shown a picture of a woman who had come into the hub three weeks earlier. The person showing me her phone asks if I remember the woman in the picture and tells me that she had died from the virus. I didn't remember her, but I said my colleague would, my neighbor who is there every day, and she did. They had chatted about the woman's grandchildren, and she had taken sweets for them. A few weeks later, we attend a memorial outside the hospital as the funeral procession took a loop through the grounds, another revolution, another life.

Our volunteers include the furloughed, the unemployed, the self-employed, the aboutto-go-traveling-and-couldn't, university students. Some have to stop because a family member or flatmate objects to the risk of spreading the virus by coming into contact with the NHS workers. We have to work in such a way that cares about other people who aren't in the space.

I'm sorry, but could you just take one of those, rather than two? We have to make sure we have enough left for your colleagues.

The light in the morning is gentle. By the afternoon, it becomes a greenhouse. There is one little plant. I'm not sure who brought it.

She left with two large bags of stuff.

I know. But we don't know her situation. It's not for us to ask.

There is tension between the initiators of the project regarding whether to target essential workers or the most vulnerable people. There are questions about how long the hub should operate, whether it is really needed as the rates of infection come down. For my neighbor, all of it is useful if it keeps people fed and remembered. When there is an excess of food in the hub, she further redistributes. Excess food reaches vulnerable families who are not getting food via schools, because they are closed. 
They like something they can carry for their breaks.

The hospital canteen is closed. Convenience and speed are now reserved for the NHS workers. Some can show their passes at the supermarkets and not have to queue. I see how packaging determines what is consumed and consumable. Everyone likes convenience. We heave bags of onions off trolleys and into boxes. We heave sighs for the entanglements of food waste and production. The responsivity of speed and design raises questions about extractive practices, which the hub can at best mediate: we will recycle the cardboard but we do not refuse the plastic-wrapped or the chemically stabilized. Hating to see things go to waste is a powerful motivator for late-night supermarket pickups, or telephoning neighbors to see if we can store spare milk in their fridges. The conditions of excess, Elizabeth Povinelli (2011: 130) observes, sit side by side with conditions of exhaustion and endurance.

In the month of April, about three hundred NHS workers were using the hub over the course of each sixteen-hour day. Roughly seventy volunteers operated both in and outside of the hub, with donations coming from more than four hundred individuals, businesses, and other groups. The sparse population inside the hub at any given time does not indicate all of these invisible hands. But the hub is also a buffer zone between the realities of the hospital (where physical distancing is impossible) and the newly quiet streets, the mostly empty buses, and the paranoia of those huddling in their homes. The mandate of the hub, with its horizontal approach to serving all workers, creates opportunities for new forms of encounter, reconfiguring social relations. The hub can only hold a certain number of people at once, but people will linger to talk if they can.

A man is living apart from his family, so that he doesn't put them at risk. He is happy to take biscuits for them the next time he can visit.

A consultant who works at the hospital came in late one night as she couldn't face queuing after the long shift. Another colleague, a cleaner, is asked by a volunteer not to take an extra drink, but the consultant offers hers and expresses that she couldn't do her job without the work of the domestic team. The details of essential work's interdependencies are exposed. 
A doctor now says hello to a porter in the morning because they chatted in the hub.

By mid-July, the church group that leases the community center wants their space back and the hub closes. For some weeks already, volunteers have asked each other and the NHS workers:

Is this place still needed?

The question attests to the struggle to decide if the work of essential workers is now no longer as essential. Who becomes more or less deserving of convenience and whose vulnerability can be responded to are questions raised by the hub, but in the end unanswerable by it.

\section{Note}

1. Italicized text is verbatim speech spoken and heard in the hub amid a polyphony of voices. Presenting this speech anonymously maintains the safety and security of workers and volunteers, as well as the cathartic ethos potentiated by a space in which free expression could take place.

\section{Author Bio}

Alexandra Baybutt, PhD, CMA, RSME is based in the United Kingdom and Europe, working as an artist, educator, and researcher.

\section{Preview Image}

Courtesy of Gilbert Mercier.

\section{References}

Barad, Karen. 2007. Meeting the Universe Halfway: Quantum Physics and the Entanglement of Matter and Meaning. Durham, NC: Duke University Press.

Beausoleil, Emily. 2015. "Embodying an Ethics of Response-ability.” Borderlands 14(2).

Despret, Vinciane. 2004. “The Body We Care for: Figures of Anthropo-zoo-genesis." Body and Society 10(2-3): 111-34. 
. 2016. What Would Animals Say if We Asked the Right Questions? Translated by Brett Buchanan. Minneapolis: University of Minnesota Press.

Han, Clara. 2016. "The Difficulty of Kindness: Boundaries, Time and the Ordinary. In The Ground Between: Anthropologists Engage Philosophy, edited by Veena Das, Michael Jackson, Arthur Kleinman, and Bhrigupati Singh, 71-93. Durham, NC: Duke University Press.

Haraway, Donna J. 2016. Staying with the Trouble: Making Kin in the Chthulucene. Durham, NC: Duke University Press. 